\title{
3. 放射光による触媒の研究†
}

\author{
松林信行 \\ 物質工学工業技術研究所機能表面化学部 \\ 305-8565 茨城県つくば市東 1-1
}

Key Words: catalyst, X-ray absorption fine structure, X-ray photoelectron spectroscopy

\section{1.はじめに}

手持ちの辞書によると, 触媒とは, 「化学反 応の速度を変える作用をあち, 反応後もそれ自 身は変化しない物質」, と書いてある。確かに 反応速度を変えるだけではあるが, 熱力学的に は可能な反応であってあ, 反応速度が非常に遅 く，百年経ってあ実際にはほとんど進まない反 応が, 触媒を加えることにより, 瞬時に進んだ りする。また, 触媒を選択することにより, 目 的とする化合物を選択的に合成することあでき る。多種多様の化合物を生産する今日の化学工 業にとっては不可欠の存在である。

触媒の性能によって, 反応条件が緩和された り収率が上がったりし，企業の収益に直接影響 するため, 触媒開発研究は力が入れられてき た。しかし, 開発手法は, 活性がありそうな物 を手当たり次第に試して, 高活性のものを探す 䄉毛爆擊的手法であった。触媒活性がなぜ生じ るかという基礎的・原理的なことについては十 分な研究はなされていなかった。そうした状況 の背景には, 触媒の構造や活性発現機構がわか らなくても，とにかく使えればいいという実利 優先の風潮もあったが，有効な研究手段が少な かったことも事実である。X線回折法など, 結

\footnotetext{
${ }^{\dagger}$ 3. Study on Catalysts by Synchrotron Radiation. Nobuyuki Matsubayashi : Surface Chemistry Department, National Institute of Materials and Chemical Research, 1-1, Higashi, Tsukuba-shi, Ibaraki Pref. 305-8565, Japan.
}

晶構造解析の有力な手段は多数存在するが, 非 結晶物質の構造解析手段は意外に少ない。ほと んどの触媒は結晶構造を持たない。というより あ, 結晶構造からはずれた欠陷構造部分におい て触媒活性が発現する。触媒として働くための 最低条件である表面や界面というだけで，バル クの結晶構造からすると欠宿構造といえる。こ のため, X 線回折などの結晶に有効な手法で は, 触媒活性点の構造を直接解析できず, 他に 非晶質に有効な手段あなかったのである。しか し, 高度に多様化した現代のニーズに対応する ためには, 旧態依然とした経験と勘に頼るやり 方では限界があり, 触媒構造の解析手段が求め られていた。そうした中，1980年前後に放射光 が利用できるようになり，放射光を用いた触媒 研究が盛んに行われるようになった。放射光が 触媒の研究に光を当てたと言える。

放射光の特性と測定手法については，これま での章で詳しく解説されているので, 本稿で は，主に放射光を用いた種々の手法による X 線吸収微細構造法 (X-ray absorption fine structure, XAFS) とX線光電子分光法 (X-ray photoelectron spectroscopy, XPS)による触 媒研究の具体例について紹介する。

\section{2. 透過 EXAFS}

不均一系固体触媒の多くは担持触媒之呼ば れ，表面積を大きくするために活性種を担体上 に分散している。活性種としては遷移金属また 
はその化合物が，また担体としてはアルミナ， シリカ, チタニアなどの酸化物が使われること が多い。担体は活性種を高分散にして表面積を 上げるための分散材としてだけではなく, 活性 種と相互作用を持ち，活性に影響を与えている と考えられている。しかし，その機構について はまだよくわかっていない。これら担持触媒は 一般に結晶性を持たず，X線回折などで構造を 解析することは困難である。EXAFS では, 共 存する担体を無視して活性種である遷移金属の 構造のみを選択的に調べることができる。活性 種として用いられることが多い遷移金属に関し ては, 周期律表の第 3 , 第 4 周期の元素は $\mathrm{K}$ 吸収端で, 第 5 周期以降は $\mathrm{L}$ 吸収端で, 比較 的容易に測定できる。

石油精製プラントなどで大量に使用されてい る水素化処理触媒の例を示そう。触媒は反応中 にさまざまな劣化作用を受け，活性が低下す る。その劣化要因としては反応原料あるいは生 成物の触媒表面上への堆積, 酸化や還元作用に よる活性金属の化学状態の変化, 活性金属の分 散状態の変化などが考えられる。こうした劣化 要因を調べるためには，できるだけ反応中と同 じ状態で測定する必要がある。透過 EXAFS では反応油が付着した状態で測定できるため, 反応中の活性金属の酸化状態之凝集状態を推測 できる。

図 1 は, 石炭液化油精製処理反応に長時間使 用した前後のアルミナ担持ニッケルータングス テン触媒の $\mathrm{WL}_{3}$ 吸収端 EXAFS のフーリエ変 換の比較を行ったあのである1)。(a) は硫化タン グステン結晶構造に対する $\mathrm{FEFF}^{2)}$ によるシ ミュレーション, (b) は硫化タングステン結晶, (c) および (d) は使用後（それぞれ反応器入口部 と出口部), (e) は予備硫化後の新触媒である。 $0.241 \mathrm{~nm}$ の W-S と $0.315 \mathrm{~nm}$ の W-W のピー クを比較することにより, 反応に使用した触媒 は予備硫化した新触媒に比べて硫化が進行し, 凝集，結晶化が進んでいることがわかる。

反応に使用した触媒は, 付着した油分を洗浄

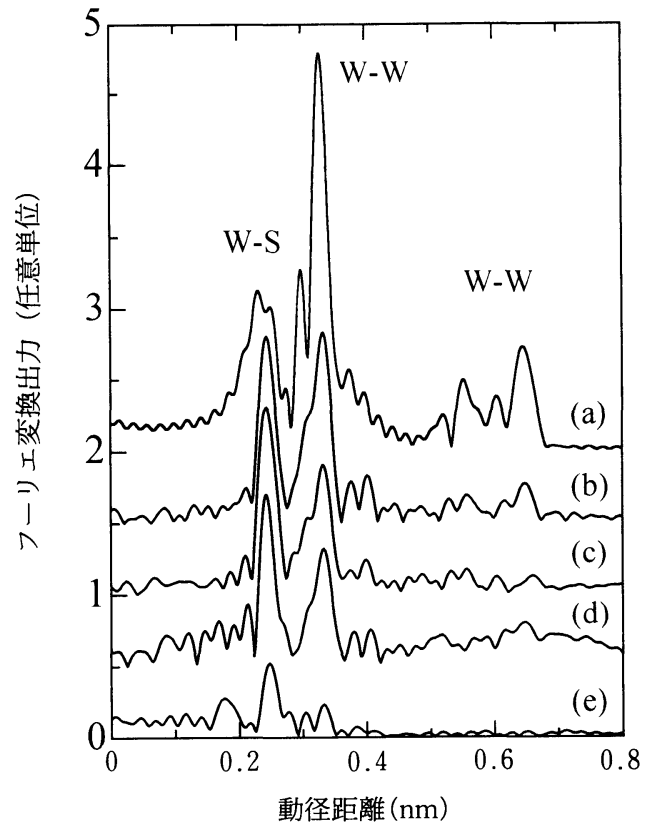

図 1 アルミナ担持ニッケルータングステン触媒 の $\mathrm{W} \mathrm{L}_{3}$ 吸収端の EXAFS のフーリエ変 換 ${ }^{1)}$

(a)硫化タングステン結晶の FEFF による シミュレーション; (b) 硫化タングステン 結晶; (c)石炭液化油精製処理反応に長時 間使用後 (反応器入口部) ; (d) 同（反応器 出口部); (e)新触媒 (予備硫化後)

することなく，そのまま窒素ガス雾囲気下で粉 砕した後成型し，ペレットにして测定したあの である。通常の解析手段では付着した油分を取 り除く必要があり, 洗浄などの前処理の間に大 気中の酸素により酸化されるため, 反応直後の 状態を調べることは困難であった。EXAFS で は, 対象とする元素や測定領域に吸収端を持つ 妨害元素が含まれていない限り，他の元素が共 存していても測定上直接の影響はない（濃度が 薄かったり重元素が共存している場合には測定 が困難になることもある）ので, 反応時の状態 に近い形で測定が可能である。

アルミナ担持触媒は成型性がよいので, 錠剤 成型器で成型して測定できる。酸素や湿度によ る変化を避けるため大気にさらしたくない場合 には，ポリエチレン等の袋に入れて密閉し，そ 
のまま測定できる。チャック付きのものは機密 性もよく便利である。ただし，プラスチック フィルムの中には, 微量の金属類を含む物もあ るので，測定しょうとする元素あるいは測定領 域に吸収端を持つ元素を含まないことを確認し た方がよい。

シリカやチタニア，ゼオライトなどの場合は 成型性があまりょくないので, 乾燥したメチル セルロース，デンプンなど軽元素でできたバイ ンダーを混ぜている。非担持の触媒など濃度が 濃すぎる場合の希釈剤としてあ有効である。た だし，用いるバインダーが試料と反応しないこ と，測定領域に吸収端を持つような元素を含ま ないことを確認しておく。

バインダーを加えたくない場合など，何らか の理由により成型ができない場合は他の方法を 用いる。濃度が濃い場合には, テープに塗布す る方法がある。濃度が薄い場合には, 粉体のま ま図 2 のようなセルを用いることができる。い ずれの場合む, 試料が不均一にならないように 注意する必要がある。図 2 の簡便なセルであ, 反応系に接続することにより, 触媒調製後ある いは反応後，まったく外気に触れさせないで測 定することができる。

反応中に触媒が作用している状態で EXAFS が測定できれば, 反応機構や触媒活性点の構造 を調べる上で理想的である。反応によっては, 高温や高圧が必要な場合ああるが，さまざまな in situ 測定用のセルが考案されている。

Neils らは, $160^{\circ} \mathrm{C}$ で 68 気圧までかけられる 高圧反応セル（図 3 ）をin situ EXAFS 測定 用に考案し，メタノール合成用の銅および覀鉛 の酸化物触媒を測定した ${ }^{3)}$ 。図 3 のような, 高 温, 高圧に使用できるセルを用いると, 反応条 件下における “その場”観察が可能となる。こ のような in situ 湘定は EXAFS の利点の一つ でああり, 多くの試みがなされているが, 空材 の問題などがあり, 実際には限られた条件でし か行われていない。また, 高圧ガスや特殊ガス を用いる場合には，技術上の問題の他に，安全

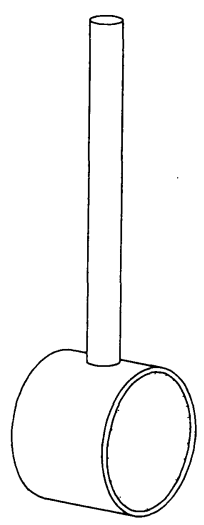

図 2 粉体用簡易 in situ EXAFS 測定セル

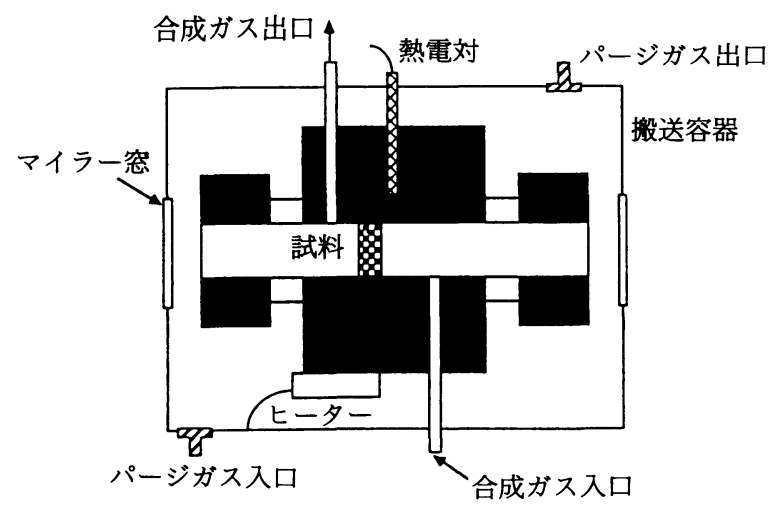

図 3 高温高圧反応用 in situ EXAFS 測定セル3)

管理上の法令の制約もあり, 放射線管理区域で ある放射光施設で実施するのは容易ではない。

\section{3. 時間分解 XAFS}

通常の XAFS は, 分光器を各エネルギーご とに掃引するステップスキャン方式であるが, 一次元位置敏感検出器を用いて全測定領域を同 時に測定する測定方法がある。この方法によれ ば, 1 回の掃引が短時間で完了し, XAFS の時 間変化が観測できるため, 測定中に試料が变化 する反応追跡手法として有効である。

Ressler らは, CO 酸化の過程での Pd 触媒 の変化を $\mathrm{Pd}$ の $\mathrm{K}$ 吸収端の変化としてとらえ だ)。図 4 は, カーボン上に担持した PdO 触 


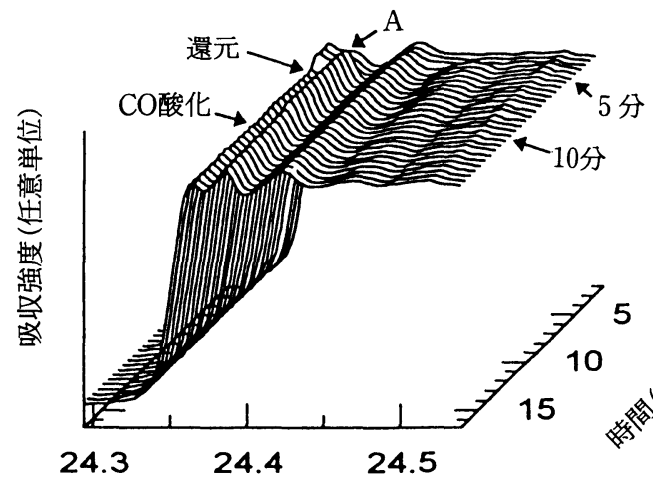

光エネルギー $(\mathrm{keV})$

図 4 活性炭担持 Pd 触媒上での CO 酸化の過 程の Pd K 吸収端時分割スペクトル4)

媒の CO による還元反応過程における $\mathrm{Pd}$ の $\mathrm{K}$ 吸収端スペクトルの変化を示している。吸収端 の構造(A)の変化から, CO による還元開始とと あに $\mathrm{PdO}$ から Pd 金属に変化していることが わかる。

触媒の場合, 積算時間が数秒は必要であり, 反応過程の変化を捉えることができるのは非常
に遅い反応に限られるが, 将来, 光源強度や検 出器が改善され, ミリ秒, マイクロ秒以下で測 定できるようになれば，応用範囲が広がるであ ろう。

\section{4. 蛍光 XAFS}

触媒では微量の添加物が活性に大きく関与す ることがある。そのような希薄試料に対して は，蛍光 X線を検出する蛍光法が有効である。 検出器としてはフィルタを用いる Lytle 型検 出器や SSD 検出器などが用いられている。

Nashner らは, Re-Ir 二元金属触媒の微細 構造を Lytle 型の触媒セルを用いて, 水素ガ ス雹囲気下 $500{ }^{\circ} \mathrm{C}$ までの昇温活性化過程の $\mathrm{XAFS}$ を, $\operatorname{Re} \mathrm{L}_{3}, \quad \operatorname{Ir} \mathrm{L}_{3}$ 両吸収端について蛍光 $\mathrm{X}$ 線により測定した5)。図 5 に，そのフーリエ 変換を示す。 $\left[\mathrm{Re}_{7} \mathrm{Ir}-\mathrm{N}\right]$ と $\left[\mathrm{Re}_{5} \mathrm{IrRe}_{2}-\mathrm{N}\right]$ は, それぞれ異なる異性体を出発物質としており, アルミナ上に担持されている。金属担持量は $0.5 \mathrm{wt} \%$ で，透過法では測定困難な濃度であ
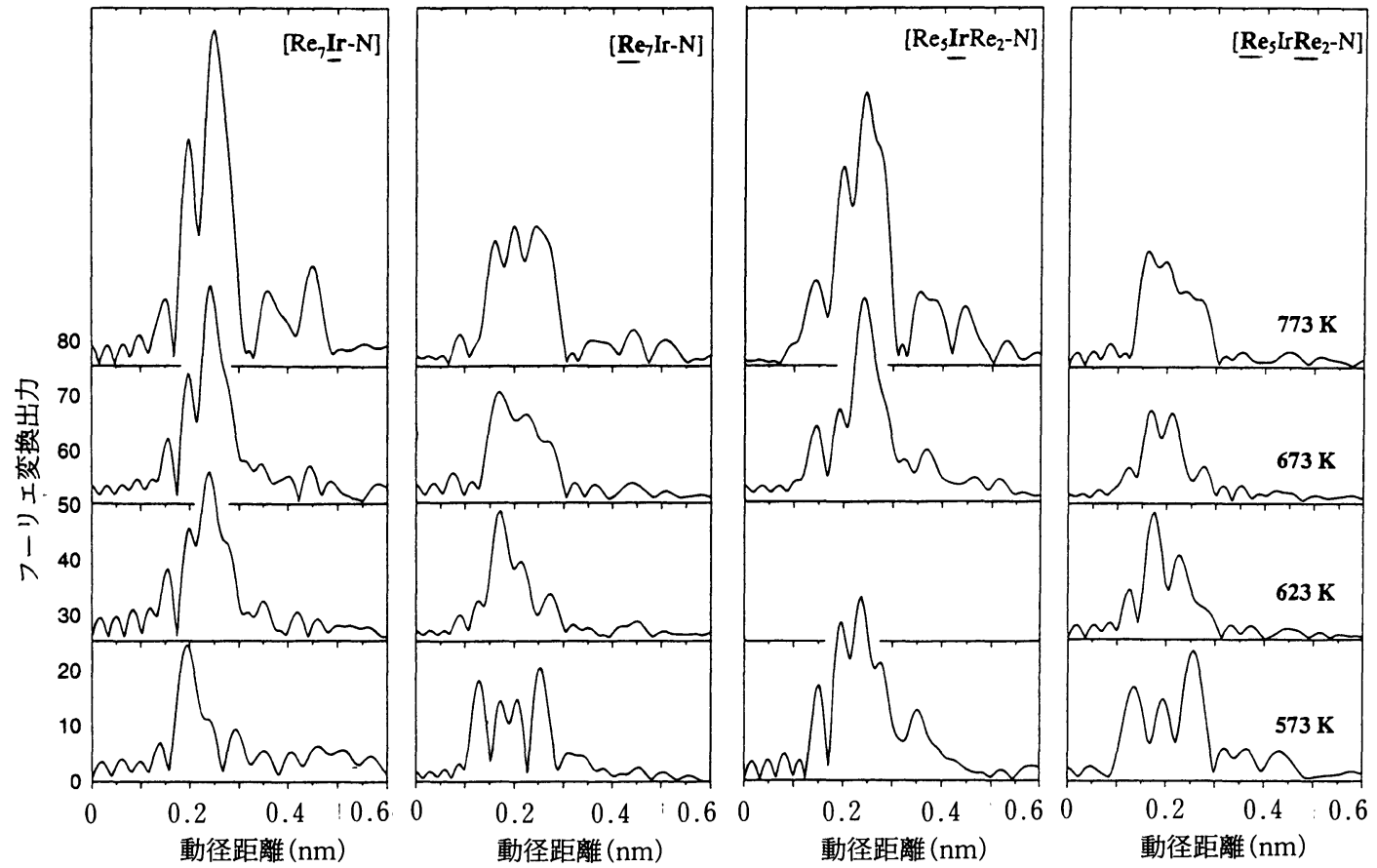

図 52 種類の異なる異性体を出発物質とするアルミナ担持 $\mathrm{Re}-\mathrm{Ir}$ 二元金属触媒の水素ガス晜囲気下での 昇温活性化過程の $\operatorname{Re~} \mathrm{L}_{3}, \mathrm{Ir} \mathrm{L}_{3}$ 両吸収端の蛍光 EXAFS のフーリエ変換 ${ }^{5}$ 
るが, 蛍光法により出発物質および還元温度の 違いによる構造変化が観測された。

透過法ではバルクの情報が得られるのに対 し，蛍光法では少し表面感度が高くなってい る。全反射条件で測定するとさらに表面感度を 上げることができる。後で述べる電子を測定す る方法と比べて真空を必要としない利点があ る。

Asakura らは，図6 のような in situ セルを 用いて全反射蛍光 XAFS を测定している6)。 圧力 $\left(10^{-9}\right.$ から $\left.10^{5} \mathrm{~Pa}\right)$ や温度 (100 から 800 K) が可変であるほか, 全反射条件下の斜入射 で偏光方向に対して角度が変えられるため, XAFS の偏光依存性を測定することができる。 図 7 は, $\alpha-\mathrm{Al}_{2} \mathrm{O}_{3}$ 結晶(0001)面上に分散させた $\left[\mathrm{Pt}_{4}\left(\mu-\mathrm{CH}_{3} \mathrm{COO}\right)_{8}\right]$ クラスターの全反射蛍光 XAFS とそのフーリエ変換である7)。(a) は p 偏光（偏光の電場べクトルと表面が直交）で, (b) は $\mathrm{s}$ 偏光（偏光の電場ベクトルと表面が平
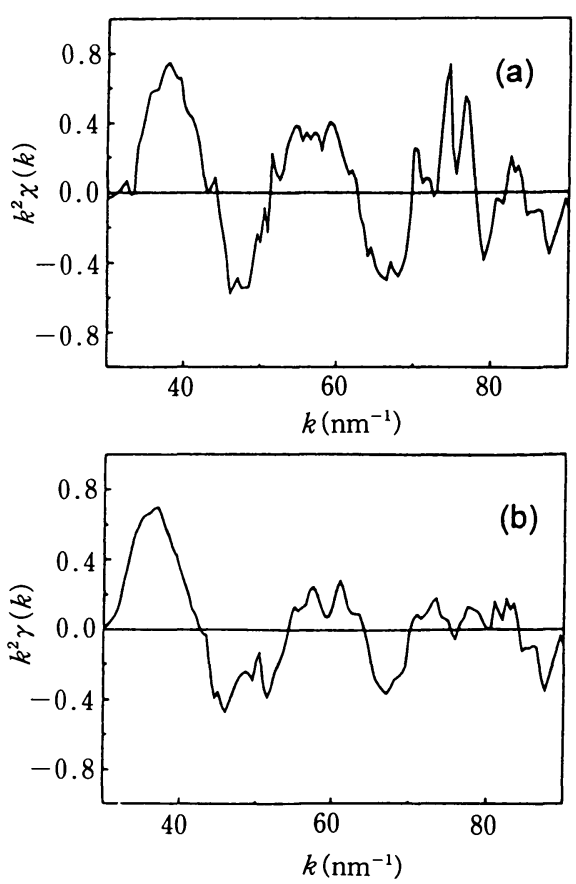

行）である。 Pt-Pt 結合に相当するピークが観 測されないことから, $\mathrm{Pt}_{4}$ クラスター構造が壊

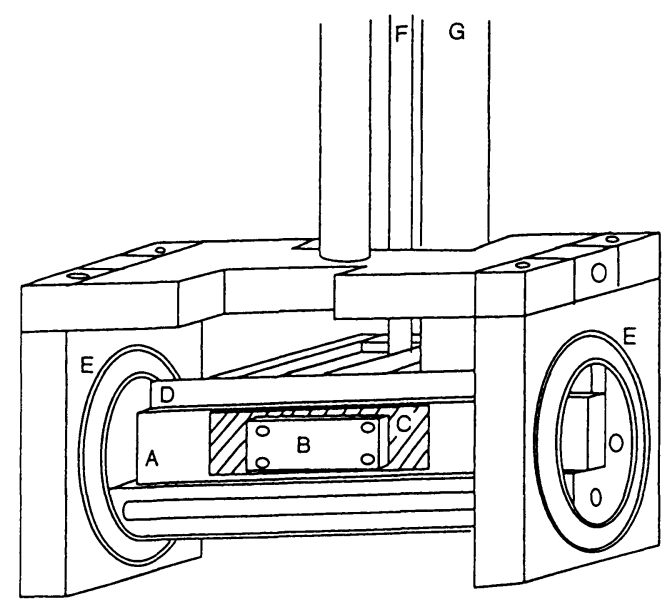

図 6 全反射蛍光 XAFS 用 in situ セル6) $\mathrm{A}: \alpha-\mathrm{Al}_{2} \mathrm{O}_{3} ; \mathrm{B}:$ 試料; $\mathrm{C}:$ タンタルヒー ター； D：試料回転筒；E：ベアリング； $\mathrm{F}$ : 直線導入棒; $\mathrm{G}$ ：液体坴素導入チュー ブ
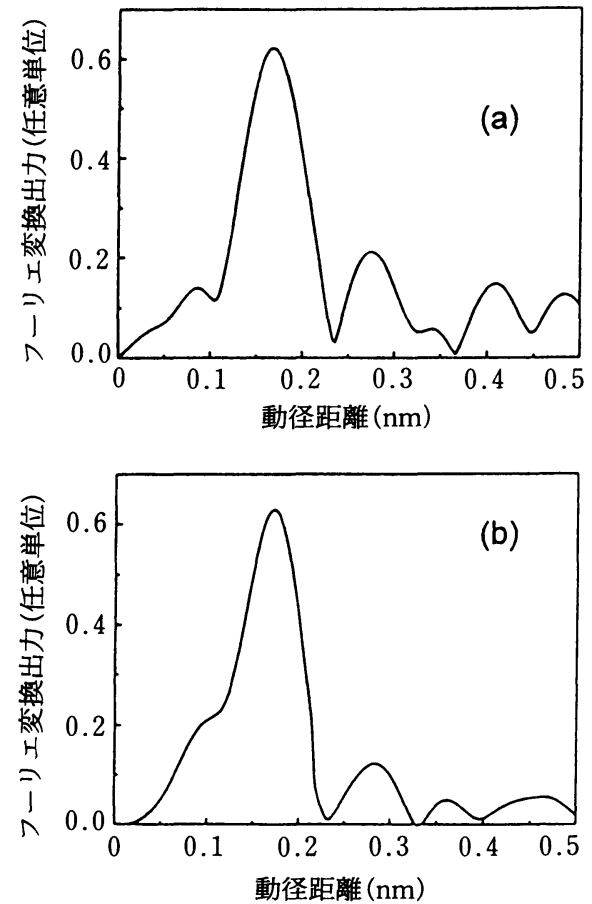

図 $7 \alpha-\mathrm{Al}_{2} \mathrm{O}_{3}$ 結晶 (0001) 面上に分散させた $\left[\mathrm{Pt}_{4}\left(\mu-\mathrm{CH}_{3} \mathrm{COO}\right)_{8}\right]$ クラスターの全反射蛍光 $\mathrm{XAFS}$ スペクトルとそのフーリエ変換 ${ }^{7)}$ 
れて，Pt は原子状に分散しているとしている。 さらに, カーブフィッティングによる詳細な解 析により, $\mathrm{Pt}$ が $\alpha-\mathrm{Al}_{2} \mathrm{O}_{3}$ 結晶 (0001) 面上で fcc または hcp の 3-fold hollow site に位置してい ると推定している。

\section{5．表面 X線吸収スペクトル}

触媒研究において, 触媒活性点上での反応分 子の吸着挙動を追跡することは, 反応機構を研 究する上で重要な意味を持つ。有機反応物質の 構成成分として重要な炭素, 窒素, 酸素などの 元素の吸収端は, $200-1000 \mathrm{eV}$ の軟 X 線領域 にある。EXAFS やXANES スペクトルと, 光電子スペクトルを組み合わせることにより, 吸着サイトの構造や酸化数, 電子状態に関する 情報などが得られるが，表面吸着原子の割合が 少なく，バルク全体に比べ信号が微弱となるこ とから, 強力な光源と高感度の分析装置が必要 となる。今のところ，ほとんどが単結晶の清浄 表面上に吸着した分子の研究など単純な系であ るが, 放射光や分光器, 検出器の性能向上によ り実用触媒に応用されることが期待される。

図 8 は, Rh 金属表面に吸着した NO の N K
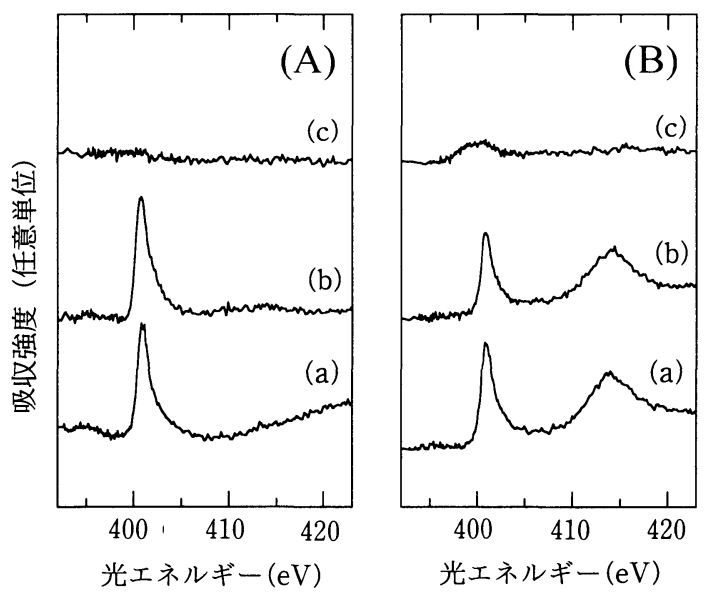

図 $8 \mathrm{Rh}$ 金属表面に吸着した NO の $\mathrm{N} \mathrm{K}$ 吸収 端スペクトル ( $^{8)}$ (A) 直入射 ( 0 度)，(B) 斜入射（60度） (a) $110 \mathrm{~K}$ で $1 \mathrm{~L}$ の NO を吸着後; (b) 室温 に昇温； (c) $605 \mathrm{~K}$ に昇温
吸収端スペクトルである ${ }^{8)}$ 。偏光を利用するた めにX線の入射角度を，(A) は直入射，(B) は斜 入射にしてある。それぞれ，(a) は $110 \mathrm{~K} て ゙ ~ 1 \mathrm{~L}$ の NO を吸着させたもの，(b) は室温に上げた あの，(c) は $600 \mathrm{~K}$ に加熱したあのである。401 $\mathrm{eV}$ と $414 \mathrm{eV}$ のピークは, それぞれ分子状に吸 着した NOの $\pi^{*}$ と $\sigma^{*}$ に州属される。(A) と(B) の差異に表されている偏光依存性は, NO の分 子軸が表面に垂直になっていることを示してい る。また，昇温により NO の解離吸着により 生じた Rh 窒化物が残存し, 偏光依存性を示す ことから，窒素が $\mathrm{Rh}$ 表面上に結合しているこ とがわかった。

\section{6. $\mathrm{X}$ 線光電子分光法}

$\mathrm{X}$ 線光電子分光法 (XPS) は表面の状態分析 の手法として広く用いられているが，通常は $\mathrm{A} 1 \mathrm{~K} \alpha(1486.6 \mathrm{eV})$ や $\mathrm{Mg} \mathrm{K} \alpha(1253.6 \mathrm{eV})$ など の特性 $\mathrm{X}$ 線を励起光として用いているため, 励起光のエネルギーを自由に選択できず, 光電 子の運動エネルギーは束縛エネルギーによって 決められる。光電子の脱出深さ（平均自由行 程）は，同じ媒質中ではその運動エネルギーに よって決まるため, 厳密には, 測定する光電子 ピークにより分析深さが異なることになる。

放射光利用の進歩により, 軟 X 線領域 (100 $1000 \mathrm{eV})$ の X 線が高強度, 高分解能で得られ るようになった。放射光光源を用いることによ り, 自由に励起 X 線のエネルギーを選ぶこと が可能になり, 光電子の運動エネルギーを選択 することにより，分析深さを選択することがで きる。図 9 は $\mathrm{NaY}$ 型ゼオライト $\left(\mathrm{SiO}_{2} / \mathrm{Al}_{2} \mathrm{O}_{3}\right.$ =4.8)の Si 2p, Al 2p, Na2s のスペクトルを 励起 $\mathrm{X}$ 線のエネルギーを変化させて測定した あのである ${ }^{9)}$ 。Si $2 \mathrm{p}$ のピーク強度により規格 化してあるが, 励起エネルギーが小さくなるに 従って, Al 2p のピークが大きくなっているこ とがわかる。このことは, $\mathrm{Al}$ が表面に局在化 していることを示している。さらに詳細な解析 により, $\mathrm{Al} / \mathrm{Si}$ の深さ方向の分布を推定するこ 


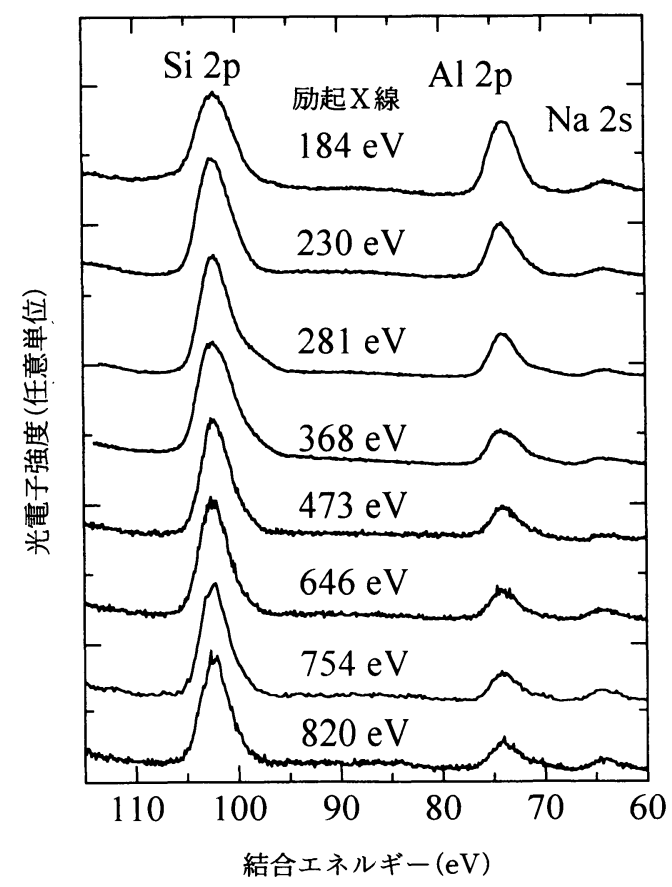

図 9 励起 $\mathrm{X}$ 線エネルギーを変化させたときの $\mathrm{Na} \mathrm{Y}$ 型ゼオライト $\left(\mathrm{SiO}_{2} / \mathrm{Al}_{2} \mathrm{O}_{3}=4.8\right)$ の $\mathrm{Si} 2 \mathrm{p}, \mathrm{Al} 2 \mathrm{p}, \mathrm{Na} 2 \mathrm{~s}$ の光電子スペクトル (Si $2 p$ により規格化 $)^{9)}$

とができる。

\section{7. まとめ}

放射光を用いた EXAFS では, 種々の測定 法が可能であり,それぞれに特徵がある。今回 紹介した以外にも, 光脱離イオン収量法 ${ }^{10)}, \mathrm{X}$ 線ラマン散乱法 ${ }^{11)}, \mathrm{X}$ 線光音響法 ${ }^{12)}$ などあ研究 されている。この多様性は触媒研究にとって有 利であり，必要な情報によって测定法を選択す ることができる。しかし，まだ比較的簡単に測 定できる透過法以外の応用例は少ない。今後, XAFS により, 触媒研究では種々の測定法の 応用とともに，目的とする反応条件に応じた in situ セルの開発が重要になるであろう。光
電子分光についても光源の高輝度高強度化によ り高分解能の X 線が高強度で得られるように なってきた。また, 光電子エネルギーアナライ ザの感度が向上し，高分解能で測定できるよう になっているので, さらに放射光が触媒研究に 応用されるようになると思われる。

\section{文献}

1) Matsubayashi, N., Sato, T., Shimada, H., Imamura, M., Yoshimura, Y., Nishijima, A., Kameoka, T. and Masuda, K.: Coal Sci. Technol., 24, 1495-1498 (1995)

2) Rehr, J. J., Albers, R. C. and Zabinsky, S. I. : Phys. Rev. Lett., 69, 3397-3400 (1992)

3) Neils, T. L. and James, M. : J. Catal., 118, 79-84 (1989)

4) Ressler, T., Hagelstein, M., Hatje, U. and Metz, W.: J. Phys. Chem. B, 101, 6680-6687 (1997)

5) Nashner, M. S., Somerville, D. M., Lane, P. D., Adler, L., Shapley, J. R. and Nuzzo, R. G. : J. Am. Chem. Soc., 118, 12964-12974 (1996)

6) Shirai, M., Nomura, M., Asakura, K. and Iwasawa, Y.: Rev. Sci. Instrum., 66, 5493-5498 (1995)

7) Asakura, K., Chun, W. J., Shirai, M., Tomishige, K. and Iwasawa, Y.: J. Phys. Chem. B, 101, 5549-5556 (1997)

8) Saito, T., Esaka, F., Furuya, K., Kikuchi, T., Imamura, M., Matsubayashi, N. and Shimada, H. : J. Electron Spec. Rel. Phenomena, in pinting

9）島田, 松林, 今村, 佐藤, 西嶋：X線分析の進歩, 27, 161-172 (1996)

10) Knotek, M. L., Jones, V. O. and Rehn, V.: Phys. Rev. Lett., 43, 300-303 (1979)

11) Tohji K. and Udagawa, Y. P : Phys. Rev. B, 36, 9410-9412 (1987)

12) Masujima, T., Kawata, H., Kataoka, M., Shiwaku, H., Yoshida, H., Imai, H., Toyoda, T. Sano, T., Nomura, M., Iida, A., Kobayashi, K. and Ando, M.: Rev. Sci. Instrum., 60, 25222524 (1989) 